Article

\title{
An Investigation on Virtual Information Modeling Acceptance Based on Project Management Knowledge Areas
}

\author{
Nasim Didehvar ${ }^{1}$, Mohammadnabi Teymourifard ${ }^{2}$, Mohammad Mojtahedi ${ }^{3, *}$ (D) and \\ Samad Sepasgozar ${ }^{3}$ \\ 1 Faculty of Architecture and Urban Planning, University of Art, Tehran 1136813518, Iran; \\ n.didehvar@alumni.ut.ac.ir \\ 2 Master of Executive Management, Shahid Beheshti University, Tehran 1983969411, Iran; \\ m.teymourifard@mail.sbu.ac.ir \\ 3 Faculty of Built Environment, University of New South Wales, Sydney 2052, Australia; sepas@unsw.edu.au \\ * Correspondence: m.mojtahedi@unsw.edu.au
}

Received: 30 April 2018; Accepted: 8 June 2018; Published: 12 June 2018

\begin{abstract}
In the contemporary construction management, poor project performance, cost overrun, and low-quality construction have become a central point of attention for improving project performance including information, interaction and communication management. Virtual design and building information modeling play indispensable role in improving the project performance. The aim of this study is to investigate the benefits and challenges of Virtual Information Modeling as a novel information and communication technology method on project management knowledge areas in the construction industry. Using one-sample $T$ test with Kolmogorov-Smirnov approach, we analyzed data collected from structured questionnaire survey involving project managers working at architecture, engineering and construction industries in Tehran, Iran. The results with $64 \%$ response rate suggest that the most important benefits and challenges of using Virtual Information Modeling are related to the area of integration, and implementation of Virtual Information Modeling has significant impact on project integration management knowledge in compare with other project management knowledge areas. Thus, integration should be considered a top priority for construction companies implementing Virtual Information Modeling in their projects. Policymakers should understand that careful management of virtual information is essential for improving the performance of projects and enhancing the process efficiency.
\end{abstract}

Keywords: virtual information modeling; project management knowledge areas; construction projects; communication management

\section{Introduction}

Construction companies have been struggling to improve their information management, interactions and communications [1]. Information and communication technology has potential to significantly reduce construction time and cost, defects, accidents, waste and operation and maintenance costs while improving predictability and productivity in construction companies [2]. However, the majority of construction business processes are still heavily based on traditional means of communication such as face-to-face meetings and the exchange of paper documents in the form of technical drawings, specifications and site instructions. This is due to historical, industrial and market forces that perpetuate the industry's culture, affecting the adoption of IT in day-to-day business processes [1]. 
The research to date has tended to focus on improving project management methods and practices [3]. Current trends in information and communication technology (ICT) are yielding a wide range of new computer-based tools to support the architecture, engineering, construction and facilities management (AEC) industries. These tools, particularly those associated with building information models (BIMs) for project modeling and integration promise great improvement in the effectiveness and efficiency of designing and managing construction projects. However, these improvements require more than just technical solutions; their full potential cannot be realized without corresponding changes in the work tasks and skill sets of the project participants [4]. Information and communication have always been important to AEC projects; however, approaches for managing information have generally been informal and ad hoc [5].

Virtual design and construction was pioneered by research over the last two decades at the Center for Integrated Facility Engineering (CIFE) at Stanford University [6]. The objective of virtual design construction is to use virtual models to simulate the complexities of construction project delivery, to understand the pitfalls project teams are likely to encounter, to analyze these pitfalls and to address them in a virtual world before any construction work takes place in the real world [7].

The adoption and implementation of virtual design and construction in the architecture, engineering and construction (AEC) industry has been growing in developed countries and has become an important strategy in the construction industry to improve productivity and profitability. Despite the many improvements and capabilities of virtual design and construction, it is still unfamiliar to the construction industry in Iran, and project managers still rely on traditional approaches. Over the past few years, some companies have been moving toward the use of new methods, but only use some of the capabilities. Construction companies in Iran are hesitant to accept and implement virtual design and construction approaches, since they are not familiar with this method, and project managers are still unaware of the benefits of implementing virtual design and construction. Therefore, the aim of this paper is to analyze the benefits and challenges of Virtual Information Modeling aligned with project management knowledge areas for AEC industry particularly for developing countries. An analysis of previous research show that Virtual Information Modeling (VIM) implementation by project managers in AEC industry particularly in developing countries like Iran is missed, in addition, far too little attention has been paid to the benefits and challenges of implementing VIM in regard to project management knowledge areas. There have been no empirical studies which compare differences in project management knowledge areas while implementing VIM. This research, therefore, intends to see the prioritization of project management knowledge areas considering the benefits and challenges of VIM implementation based on project managers' perspectives in AEC industry. The research to date has tended to focus on VIM implementation rather than project management knowledge areas prioritization for VIM implementation.

The paper is structured as follows. First, the VIM method is introduced briefly through a literature review. Then the benefits and challenges identified from the literature are categorized according to project management knowledge areas. Then, using a questionnaire distributed to employees in the AEC industry in Tehran province in Iran, the benefits and challenges of proposed VIM are investigated and prioritized based on their applicability's in AEC industry.

\section{Virtual Information Modeling from Design to Construction}

\subsection{Terms and Concepts}

Technology is generally defined as a technological solution in the context of construction industry. For example, it refers to tools, machines, and modifications to these tools that are used to achieve a project goal and perform a specific function or may resolve a problem in the context of the construction industry $[8,9]$. Technology in construction generally embraces digital devices, spatial analysis systems, hand tools and excavation equipment and any combination of resources used in the process of construction operation from design to construction and demolition [10-12]. In this paper, Virtual 
Information Modeling (VIM) refers to two widely used concepts in the construction literature: virtual design and construction and building information modeling.

The Center for Integrated Facility Engineering (CIFE) defines virtual design and construction as the use of multi-disciplinary performance models covering design to construction, including the facilities, work processes and organization of the design and construction teams in order to support the construction project objectives. This concept allows a construction practitioner to build symbolic models of the building, design organization and the design or construction processes early before a large commitment to the client is made. Thus this supports mainly design and construction managers in terms of the description, evaluation, prediction and decisions about a project's scope, organization and schedule with virtual methods [7].

A three-stage maturity model of development has been suggested for VIM by Khanzode, Fischer et al. [7]: (i) The first stage is visualization which was illustrated by using two-dimensional (2D) approaches such as CPM (Critical Path Method) and bar charts. The aim of visualization is to represent design and rehearse construction processes through visual simulation, three-dimensional (3D) technologies and virtual reality; (ii) The second stage of VIM is integration which aims to integrate various processes and different disciplines involved in a project; (iii) The third stage of VIM is automation which aims to automate some of the tasks in the design and construction processes. Currently, design and construction planning are creative work undertaken exclusively by humans; VIM provides a good platform for this work [7].

As defined in National BIM Standard (NBIMS) issued by building SMART alliance ${ }^{\circledR}$ defines BIM as "a digital representation of physical and functional characteristics of a facility" [13]. Building Information Modeling was utilized by practitioners as a significant opportunity in the architecture, engineering and construction industry. It is an emerging concept which is known as a solution to facilitate the integration and management of information throughout the building life cycle. Previous studies presented several case studies and applications of this technology [14-16].

The scope of the definition of virtual design and construction is broader than that of building information modeling, but both concepts give us a comprehensive view of utilizing a new technology for both design and construction at different levels of office and project. The building information modeling concept tends to cluster around a 3D model and visualize the technical aspects of a project, virtual design and construction encompasses multi-disciplinary use of the models and social methods for achieving the project goals. The virtual design and construction also stresses the loop between defining objectives and rendering solutions with optimization and automation. Hence while building information modeling and virtual design and construction share similar characteristics, there are subtle additions to virtual design and construction in regard to the scope of modeling, the drivers of modeling, and social methods for leveraging those models, making it more comprehensive and holistic than building information modeling. However, since many entities and individual projects across the industry set forth their own definition of building information modeling, some may argue that building information modeling also includes these additional characteristics. With this understanding in mind, i.e., with a broader definition of building information modeling that matches virtual design and construction, both concepts the virtual design and construction and building information modeling, namely VIM can be represent all relevant technologies in construction [17].

While previous concepts pointed out to the technology itself, and the applications, they did not give an insight into the process of the technology acceptance in a specific context. According to Rogers [18], technology acceptance is defined as a series of steps taken in the technology utilization process. In this process, a technology user passes through the process results in accepting or rejecting the utilization of the VIM technology. Sepasgozar et al. [19] classifies the technology adoption into three major clusters from different perspectives: (i) Socio-economic perspective [20]; (ii) managerial perspective [8]; and (iii) psychological perspective [21,22]. Studies that take a socio-economic perspective such as Rogers [18] focused on profiling the users of particular technologies in different disciplines. Rogers [20] suggested that technology acceptance occurs within a social system, where 
potential adopters communicate with each other based on a variety of attitudes towards technology utilization. Roger's formative model includes five groups of technology adopters: innovators; early adopters; early majority adopters; late majority adopters; and laggards. The key concept of this theory relies on the concept of innovation relative to individual behavior, their relationships in a social context, and communication. Research in construction adopted the concepts and applied them in a way similar to other industries.

While there is some attempt to identify the barriers of technology adoption, the construction industry continues to lag in utilizing new technologies, and is generally adverse to change as discussed by Nicolini [23]; Bowden et al. [2]; Nikas et al. [24]; Harty [25]; Sepasgozar et al. [26], Milliou and Petrakis [27]. The Melbourne Institute of Applied Economics and Social Research [28] indicates that the construction technology index is significantly lower than any other industries. This index had a large fell by $18.2 \%$ between 2005 and 2006. For example, Hinsch et al. [29] studied on photovoltaic modules in Fraunhofer Institute for Solar Energy Systems (ISE) and reported that the Dye Solar Cells (DSC) is investigated as a new technology since 15 years. Hinsch [30] wondered why only a small portion of the photovoltaic modules was adopted by builders in construction market so far, when the photovoltaic application has a strong market in overall. Cleveland [31] identified a group of emerging technologies that may enable construction projects and support construction operation in the field. However, he concluded that there are significant barriers to be investigated and challenges to be addressed and several hurdles to overcome for adoption. The adverseness to risk and the technology acceptance lag is due to many reasons such as the stakeholders expectations and communication, variability of a project's expertise, the uniqueness of the technology [32] and the nature of industry itself [33] e.g., in developing country. These reasons make the construction industry very different compared to other industries. This is extradited since the technology acceptance and utilization processes in construction is not clearly understood, while they are mature streams in other disciplines such as Information System (see: Vessey et al. [34]; Venkatesh et al. [35]).

The main concept of technology acceptance goes back to decades ago when Howard and Moore ([36], p. 34) found that the technology users' path to a utilization decision consists of a series of mental or behavioral steps that potential adopters pass through. This might be coupled with organizational factors when we analyze the adoption process including benefits and challenges at the project level. Here, Adoption description reveals the necessary steps to introduce a product into the daily operations of an organization [37]. A well-known psychological model of Theory of Reasoned Action (TRA) developed by Ajzen and Fishbein [38] is concerned with the indicators of conscious intention and users attitude towards a behavior.

Davis et al. [21] developed their model based on the Theory of Reasoned Action, namely technology acceptance model including two main contracts presented in Figure 1. These constructions are useful to predict individual behavior applied to the field of VIM technology. Sepasgozar et al. [19] analyzed technology acceptance model, as a predictor of the an information technology acceptance. The main constructions are usefulness and ease of use.

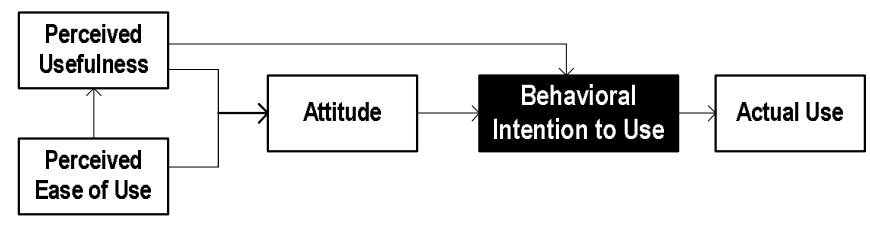

Figure 1. Technology Acceptance Model (Source: Sepasgozar et al. [19] adopted Davis [21]).

\subsection{The Gap of Understanding Construction Technology Adopters at Organizational Level}

The literature ignored to continue investigating the barriers and drivers of technology acceptance mainly VIM in developing countries. Since we understate the subjectivity of the barriers as perceived by their participants, it is no surprise that they overlooked some fundamental factors relevant to 
the context including developing countries in the literature of innovation adoption. The innovation diffusion literature [18] emphasize that (a) technology acceptance is based the perception that the VIM meets (or fails to meet) a desired level of utilization; and then (b) the process of reducing the uncertainty of the perceived acceptance of VIM is largely depends on individuals interactions in a project or organization, which is a peer to peer process. This concept poorly understood in the literature. For example, Rahman's [39] deduction that a policy intervention may give a better information dissemination about the benefits of modern methods in construction is valuable. However, as mentioned above, they omitted the fact that some companies may be the wrong target market for such a policy, and also overlooked the fact that many of the relevant stakeholders already communicate with each other via site visits and social media, and exhibitions.

In order to extend the body of knowledge, it is essential to consider previous scientific investigations in the field of technology adoption. The paper by Rahman [39] demonstrates how neglecting established work in the innovation literature may lead to significant confusion. According to Rahman [39], the technology acceptance model can be seen as a series of stages in the utilizing process through which the technology user passes.

The OECD reports [40] indicate that the construction industry is one of the highest of almost 30 industries in terms of its sourcing modules from intermediaries. Sepasgozar et al. [41] carefully examined the literature and points to the poor understanding of the technology adoption process in the construction literature. For example, Rahman [39] contextualizes a claim of low modern methods in construction uptake by identifying that $7 \%$ of low rise multifamily homes are built by using modern methods in construction, the author also identifies that modern methods in construction are inappropriate for small scale projects, because of (a) the high overhead costs of utilizing a modern method and (b) the high cost per unit when quantities of technology applications is low. If the adoption of modern methods in construction is not beneficial for small companies. Therefore, promoting a new technology and its application and benefits to them may actually be counterproductive and contribute to technology failure or the company failure. Figure 2 categorizes factors derived from the literature which will be used for developing the criteria for identifying VIM benefits and challenges.

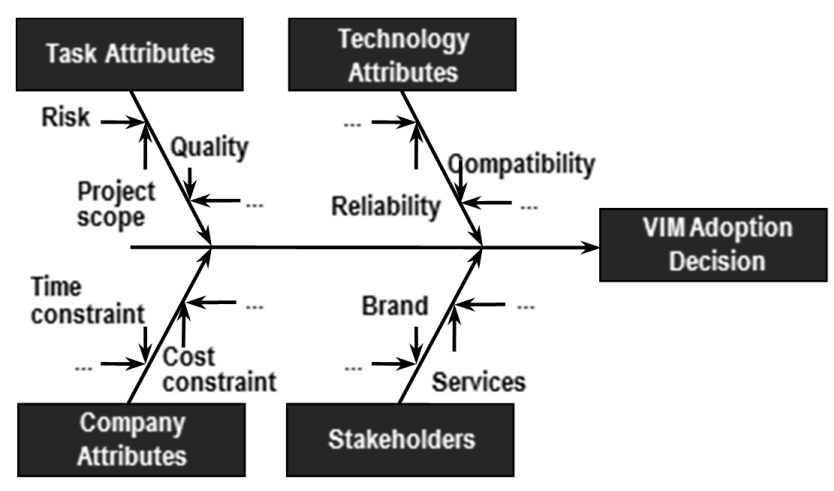

Figure 2. Fishbone framework of the influential factors in Virtual Information Modeling (VIM) adoption decision.

Existing research in construction has considered the financial aspects of technology selection using conventional investment justification, and the implementation and evaluation of particular technologies [42,43]. Whereas many typologies of adoption have been ignored such as process innovation, and barriers of technological administrative innovations. In addition, stakeholders and individuals, specifically technological gatekeepers, who attempt to find and get aware from a new technology, have important roles and may significantly influence the adoption. Scholars such as Slaughter [44]; Stewart and Tatum [45] investigated several innovations, and they pointed that innovators such as idea generator who face to a challenge in a construction project also may significantly influence the technology adoption, and can be a gatekeeper, e.g., an innovative designer in 
a contractor organization. A summary of benefits of implementing the virtual design and construction approach are classified according to nine areas of project management knowledge [46] are shown if Table 1.

Table 1. Benefits of VIM Application.

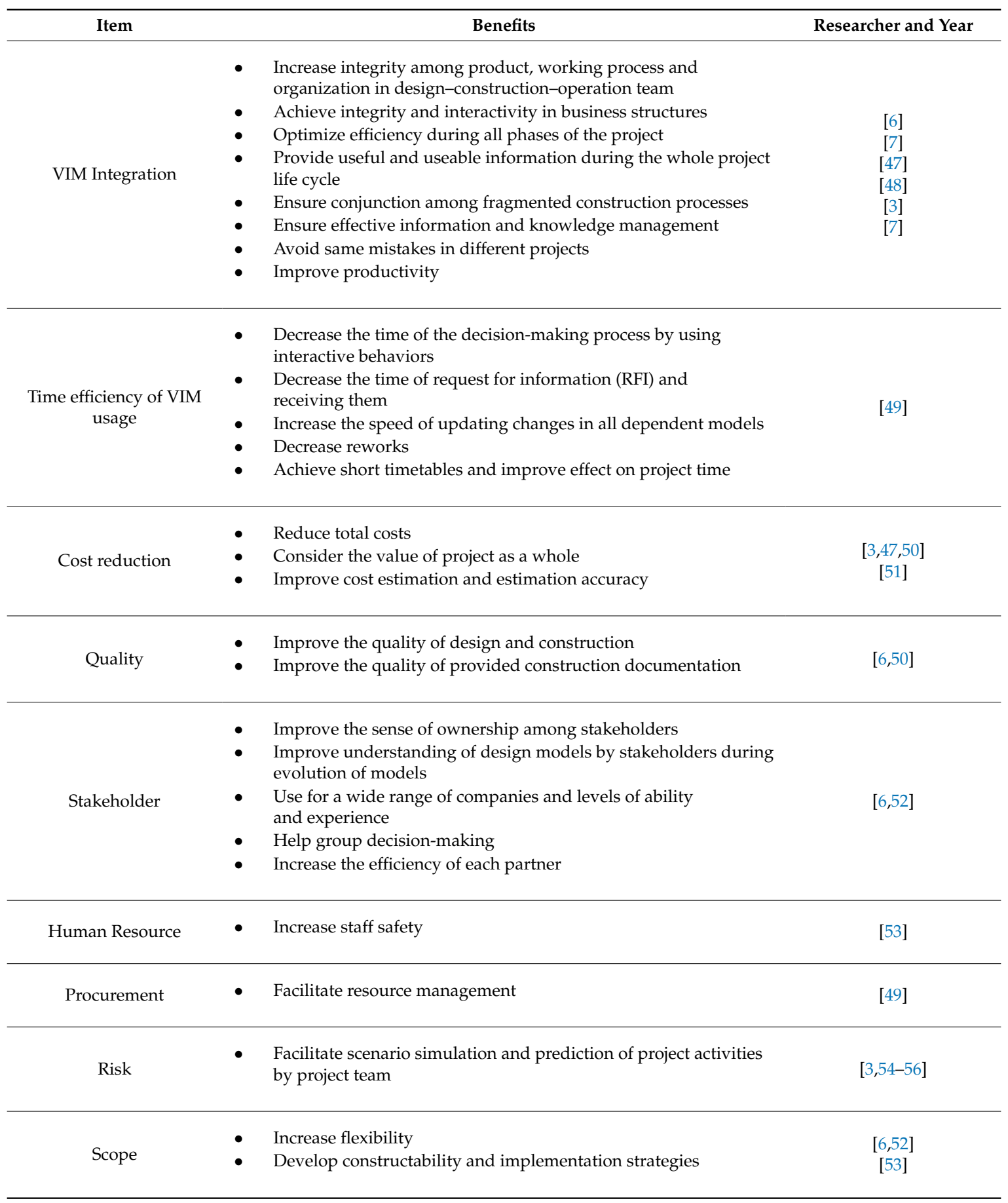

Note: Items refer to the Project Management Knowledge Areas [46].

A summary of challenges of implementing the VIM are classified according to several areas of project management knowledge [46] are shown in Table 2. 
Table 2. Challenges of VIM Application.

\begin{tabular}{|c|c|c|}
\hline Items & Challenges & Researcher and Year \\
\hline \multirow{3}{*}{ Integration } & Need for multi-party collaboration contracts & \multirow{2}{*}[6,52]{} \\
\hline & Need to change processes of project organization & \\
\hline & $\begin{array}{l}\text { Lack of software compatibility from one project to } \\
\text { another }\end{array}$ & [3] \\
\hline Time & $\begin{array}{l}\text { Creating all models at the optimum level of detail } \\
\text { and accuracy and reducing design speed }\end{array}$ & [3] \\
\hline \multirow{3}{*}{ Cost } & Excessive cost of software and hardware tools & {$[6,52]$} \\
\hline & Controversy over who should pay for VIM & [3] \\
\hline & Creating training and learning costs & \\
\hline Stakeholder & $\begin{array}{l}\text { The need for all stakeholders to agree on standards } \\
\text { for exchange between different models }\end{array}$ & {$[6,52]$} \\
\hline Human Resource & Need for a high level of expertise & [53] \\
\hline Risk & $\begin{array}{l}\text { The existence of innovative processes and the risk of } \\
\text { change }\end{array}$ & {$[3,54-56]$} \\
\hline
\end{tabular}

Note: Items refer to the Project Management Knowledge Areas [46].

Tables 1 and 2 present that scholars have conducted research to come up with the benefits and challenges of VIM implementation in AEC industry considering project management knowledge areas $[3,4]$. The issue of prioritization of project management knowledge areas for benefits and challenges of VIM implementation is still controversial and to date there is little agreement on what project management knowledge areas need to be focused more in compare with other areas for maximizing the benefits and minimizing the challenges of VIM implementation. No research has been found to prioritize the benefits and challenges of VIM implementation based on project management knowledge areas.

\section{Materials and Methods}

The construction industry of Tehran Province is divided into two main sectors. The first is government infrastructure projects and the second is the housing industry. In recent years, the construction industry has been thriving due to an increase in national and international investment to the extent that it is now the largest in the Middle East region. The purpose of this research is to study the benefits and challenges of applying virtual information modeling in construction projects in Tehran, Iran based on project management knowledge areas. This research recognizes the benefits and challenges of applying VIM in projects, and classifies them according to areas of project management knowledge, in order to specify the significance of the benefits and challenges in project success.

The variables of the study are the variables which are identified for investigating the benefits and challenges of applying VIM in projects which contain specified indicators in each of ten areas of project management knowledge: integration, time, cost, communications, quality, stakeholder, human resource, procurement, risk and scope (Snyder 2014). The research hypothesis is "the identified benefits and challenges in each of the ten areas of project management knowledge influence the successful completion of a project".

This study used a survey research design because it provides a relatively quick and better method of collecting information from targeted samples and addressing research objectives. Collecting VIM data is a time-consuming process, and all data has not been recorded; thus, a questionnaire is a quick way of collecting data and it is an appropriate tool for empirical research and can generalize findings by testing the hypotheses. The sample population for the research was employees in the AEC industry 
in Tehran province in Iran who are familiar with VIM and are likely to apply it in their organization's projects. A survey was comprised of tailored measurement scales with 30 questions pertinent to VIM benefits and 10 questions related to challenges of VIM application in projects, based on the literature review results were classified into ten areas of project management knowledge. The survey response rate was $64 \%$. Table 3 presents the summary of respondents' profile.

Table 3. Summary of respondents' profile.

\begin{tabular}{|c|c|c|c|}
\hline Item & Range & Number & Percent \\
\hline \multirow{2}{*}{ Gender } & Male & 24 & $75 \%$ \\
\hline & Female & 8 & $25 \%$ \\
\hline \multirow{4}{*}{ Age $(x)$} & $x \leq 35$ & 9 & $28 \%$ \\
\hline & $36 \leq x \leq 45$ & 14 & $44 \%$ \\
\hline & $46 \leq x \leq 55$ & 6 & $19 \%$ \\
\hline & $\overline{56} \leq x$ & 3 & $9 \%$ \\
\hline \multirow{3}{*}{ Educational Level } & Bachelor & 6 & $19 \%$ \\
\hline & Master & 22 & $69 \%$ \\
\hline & PhD or above & 4 & $12 \%$ \\
\hline \multirow{6}{*}{ Education } & Architecture & 7 & $22 \%$ \\
\hline & Civil Engineering & 13 & $41 \%$ \\
\hline & Construction & 8 & $25 \%$ \\
\hline & Management & 8 & $25 \%$ \\
\hline & Industrial Engineering & 3 & $9 \%$ \\
\hline & Mechanical Engineering & 1 & $3 \%$ \\
\hline \multirow{5}{*}{$\begin{array}{c}\text { Experience in } \\
\text { Construction Industry in } \\
\text { Years }(y)\end{array}$} & $\mathrm{y} \leq 5$ & 4 & $13 \%$ \\
\hline & $6 \leq \bar{y} \leq 10$ & 9 & $28 \%$ \\
\hline & $11 \leq \mathrm{y} \leq 20$ & 11 & $34 \%$ \\
\hline & $21 \leq \mathrm{y} \leq 30$ & 5 & $16 \%$ \\
\hline & $31 \leq \mathrm{y}$ & 3 & $9 \%$ \\
\hline \multirow{3}{*}{$\begin{array}{l}\text { Understanding the VIM } \\
\text { Concept }\end{array}$} & Yes & 26 & $81 \%$ \\
\hline & To a certain Extent & 6 & $19 \%$ \\
\hline & No & 0 & $0 \%$ \\
\hline
\end{tabular}

\section{Results of the Structured Survey}

Content validity was used to evaluate the survey validity. The draft survey was discussed by professors and specialists in this field and after the recommended changes were made, the final survey was prepared. To evaluate the reliability of the survey, Cronbach's Alpha Test was used in SPSS software. The acceptable coefficient in this test is 0.7 and as the Cronbach's Alpha is closer to one, the questionnaire will have a better reliability [57]. Table 4 shows the results. To specify the way data has been distributed, the inferential statistics method was used through the Kolmogorov-Smirnov Test in IBM SPSS Statistics 24 software (IBM Corp. Released 2016. IBM SPSS Statistics for Windows, Version 24.0. Armonk, NY: IBM Corp.). A One-Sample $T$ Test was used for confirmation or rejection of the benefits and challenges of applying VIM which were identified in the literature review. The Friedman Test was used to study the equality or inequality of the significance of benefits and challenges of VIM application through the One-Sample $T$ Test.

Table 4. Reliability of Survey: Cronbach's Alpha Coefficient.

\begin{tabular}{cccc}
\hline Benefits/Challenged of VIM & N of Items & N & Cronbach's Alpha \\
\hline Benefits of VIM & 30 & 32 & 0.848 \\
Challenges of VIM & 10 & 32 & 0.739 \\
\hline
\end{tabular}




\subsection{Kolmogorov-Smirnov Test}

Table 5 shows the results of the Kolmogorov-Smirnov Test for all of the research variables. The distribution of all research data variables (benefits and challenges) was normal, so parametric tests were used for variable tests and inferential analysis.

Table 5. Results of the Kolmogorov-Smirnov Test.

\begin{tabular}{ccccc}
\hline Benefits/Challenges & Variables & $\begin{array}{c}\text { Kolmogorov-Smirnov } \\
\mathbf{Z}\end{array}$ & $\begin{array}{c}\text { Asymp. Sig. } \\
\text { (2-Tailed) }\end{array}$ & Result \\
& integration & 1.25 & 0.088 & Normal data \\
& time & 1.176 & 0.145 & Normal data \\
& cost & 1.038 & 0.195 & Normal data \\
Benefits of VIM & communications & 1.288 & 0.067 & Normal data \\
application & quality & 1.296 & 0.061 & Normal data \\
& stakeholder & 1.151 & 0.142 & Normal data \\
& human resource & 1.135 & 0.152 & Normal data \\
& procurement & 1.268 & 0.08 & Normal data \\
& risk & 0.974 & 0.299 & Normal data \\
\hline Scope & 1.355 & 0.051 & Normal data \\
Challenges of VIM & integration & 0.896 & 0.398 & Normal data \\
& time & 1.303 & 0.067 & Normal data \\
& cost & 1.255 & 0.086 & Normal data \\
& stakeholders & 1.295 & 0.069 & Normal data \\
& human resources & 0.985 & 0.305 & Normal data \\
\hline
\end{tabular}

\subsection{One-Sample T Test for Analysis of the Benefits of VIM Application}

The benefits of applying VIM are classified according to the ten project management knowledge areas. The results of the statistical analysis of each of the 30 benefits are presented in Table 6 . 
Table 6. Results of one-sample T-test for the evaluation of benefits.

\begin{tabular}{|c|c|c|c|c|c|c|c|}
\hline \multirow{3}{*}{ Variables } & \multicolumn{6}{|c|}{ Test Value $=3$} & \multirow{3}{*}{ Result } \\
\hline & \multirow{2}{*}{$\mathrm{T}$} & \multirow{2}{*}{ df } & \multirow{2}{*}{ Mean } & \multirow{2}{*}{ Sig. (2-Tailed) } & \multicolumn{2}{|c|}{ 95\% Confidence Interval of the Difference } & \\
\hline & & & & & Lower & Upper & \\
\hline Achieve integrity and interactivity in business structures & 12.571 & 31 & 4.6562 & 0 & 1.3875 & 1.925 & confirmed \\
\hline Optimize efficiency during all phases of the project & 15.092 & 31 & 4.625 & 0 & 1.4054 & 1.8446 & confirmed \\
\hline Provide useful and useable information during the whole project life cycle & 12.661 & 31 & 4.5938 & 0 & 1.337 & 1.8505 & confirmed \\
\hline Ensure conjunction among fragmented construction processes & 7.628 & 31 & 4.4062 & 0 & 1.0302 & 1.7823 & confirmed \\
\hline Improve productivity & 11.787 & 31 & 4.375 & 0 & 1.1371 & 1.6129 & confirmed \\
\hline $\begin{array}{l}\text { Increase integrity among product, working process and organization in } \\
\text { design-construction-operation team }\end{array}$ & 12.771 & 31 & 4.375 & 0 & 1.1554 & 1.5946 & confirmed \\
\hline Ensure effective information and knowledge management & 7.915 & 31 & 4.0625 & 0 & 0.7887 & 1.3363 & confirmed \\
\hline Avoid same mistakes in different projects & 7.309 & 31 & 4.125 & 0 & 0.8111 & 1.4389 & confirmed \\
\hline Integration & 16.07 & 31 & 4.4023 & 0 & 1.2244 & 1.5803 & confirmed \\
\hline Achieve short timetables and improve effect on project time & 13.552 & 31 & 4.5938 & 0 & 1.3539 & 1.8336 & confirmed \\
\hline $\begin{array}{l}\text { Decrease the time of the decision-making process by using interactive } \\
\text { behaviors }\end{array}$ & 7.155 & 31 & 4.0625 & 0 & 0.7596 & 1.3654 & confirmed \\
\hline Decrease the time of request for information (RFI) and receiving them & 4.706 & 31 & 3.625 & 0 & 0.3541 & 0.8959 & confirmed \\
\hline Increase the speed of updating changes in all dependent models & 6.664 & 31 & 4.0938 & 0 & 0.759 & 1.4285 & confirmed \\
\hline Time & 13.416 & 31 & 4.0938 & 0 & 0.9275 & 1.26 & confirmed \\
\hline Decrease reworks & 12.636 & 31 & 4.3438 & 0 & 1.1269 & 1.5606 & confirmed \\
\hline Reduce total costs & 9.843 & 31 & 4.25 & 0 & 0.991 & 1.509 & confirmed \\
\hline Consider the value of project as a whole & 11 & 31 & 4.375 & 0 & 1.1201 & 1.6299 & confirmed \\
\hline Improve cost estimation and estimation accuracy & 5.036 & 31 & 3.75 & 0 & 0.4463 & 1.0537 & confirmed \\
\hline Cost & 14.404 & 31 & 4.1797 & 0 & 1.0126 & 1.3467 & confirmed \\
\hline Facilitate communications and interactions among stakeholders & 7.4 & 31 & 4.1562 & 0 & 0.8376 & 1.4749 & confirmed \\
\hline Reduce complicated bureaucracies and solve problems more easily & 2.247 & 31 & 3.3438 & 0 & 0.0317 & 0.6558 & confirmed \\
\hline Communications & 6.099 & 31 & 3.75 & 0 & 0.4992 & 1.0008 & confirmed \\
\hline Improve the quality of design and construction & 7.506 & 31 & 4.0625 & 0 & 0.7738 & 1.3512 & confirmed \\
\hline Improve the quality of provided construction documentation & 8.92 & 31 & 4.2812 & 0 & 0.9883 & 1.5742 & confirmed \\
\hline Quality & 9.284 & 31 & 4.1719 & 0 & 0.9144 & 1.4293 & confirmed \\
\hline
\end{tabular}


Table 6. Cont.

\begin{tabular}{|c|c|c|c|c|c|c|c|}
\hline \multirow{3}{*}{ Variables } & \multicolumn{6}{|c|}{ Test Value $=3$} & \multirow{3}{*}{ Result } \\
\hline & \multirow{2}{*}{$\mathrm{T}$} & \multirow{2}{*}{ df } & \multirow{2}{*}{ Mean } & \multirow{2}{*}{ Sig. (2-Tailed) } & \multicolumn{2}{|c|}{ 95\% Confidence Interval of the Difference } & \\
\hline & & & & & Lower & Upper & \\
\hline $\begin{array}{l}\text { Improve understanding of design models by stakeholders during } \\
\text { evolution of models }\end{array}$ & 7.642 & 31 & 4.125 & 0 & 0.8247 & 1.4253 & confirmed \\
\hline Improve the sense of ownership among stakeholders & 0 & 31 & 3 & 1 & -0.3172 & 0.3172 & rejected \\
\hline Increase the efficiency of each partner & 0.338 & 31 & 3.0625 & 0.737 & -0.3144 & 0.4394 & rejected \\
\hline Use for a wide range of companies and levels of ability and experience & 7.721 & 31 & 4.25 & 0 & 0.9198 & 1.5802 & confirmed \\
\hline Help group decision-making & 7.726 & 31 & 4.1562 & 0 & 0.851 & 1.4615 & confirmed \\
\hline Stakeholders & 7.93 & 31 & 3.7188 & 0 & 0.5339 & 0.9036 & confirmed \\
\hline Increase staff safety & 0.892 & 32 & 3.125 & 0.379 & -0.1609 & 0.4109 & rejected \\
\hline Human resources & 0.892 & 32 & 3.125 & 0.379 & -0.1609 & 0.4109 & rejected \\
\hline Facilitate resource management & 3.985 & 31 & 3.422 & 0 & 0.2086 & 0.5711 & confirmed \\
\hline Procurement & 3.985 & 31 & 3.422 & 0 & 0.2086 & 0.5711 & confirmed \\
\hline $\begin{array}{l}\text { Facilitate scenario simulation and prediction of project activities by project } \\
\text { team }\end{array}$ & 3.544 & 31 & 3.352 & 0 & 0.1988 & 0.5105 & confirmed \\
\hline Risk & 3.544 & 31 & 3.352 & 0 & 0.1988 & 0.5105 & confirmed \\
\hline Increase flexibility & 3.999 & 31 & 3.437 & 0 & 0.2144 & 0.6606 & confirmed \\
\hline Develop constructability and implementation strategies & 3.579 & 31 & 4.062 & 0 & 0.7331 & 1.3919 & confirmed \\
\hline Scope & 3.681 & 31 & 3.75 & 0 & 0.5211 & 0.9789 & confirmed \\
\hline
\end{tabular}




\subsection{Friedman Test for Prioritizing the Benefits of VIM Application}

The Friedman Test was used to prioritize the benefits of VIM which were confirmed in the One-Sample $T$ Test. The results for this test are shown in Tables 7 and 8.

Table 7. Test s of Friedman test for prioritization of benefits of VIM.

\begin{tabular}{cc}
\hline $\mathbf{N}$ & 32 \\
\hline Chi-Square & 210.606 \\
df & 26 \\
Asymp. Sig. & 0.000 \\
\hline
\end{tabular}

Table 8. Average rating of benefits of VIM among the confirmed benefits.

\begin{tabular}{|c|c|c|}
\hline Benefit & Average Rating & Benefit Priority \\
\hline Achieve integrity and interactivity in business structures & 19.58 & 1 \\
\hline Optimize efficiency during all phases of the project & 18.78 & 2 \\
\hline Achieve short timetables and improve effect on project time & 18.55 & 3 \\
\hline $\begin{array}{l}\text { Provide useful and useable information during the whole project life } \\
\text { cycle }\end{array}$ & 18.39 & 4 \\
\hline Provide conjunction among fragmented construction processes & 17.66 & 5 \\
\hline Consider the value of project as a whole & 16.38 & 6 \\
\hline Improve productivity & 16.2 & 7 \\
\hline $\begin{array}{l}\text { Increase integrity among product, working process and organization in } \\
\text { design-construction-operation team }\end{array}$ & 16.16 & 8 \\
\hline Decrease reworks & 15.95 & 9 \\
\hline Use for a wide range of companies and levels of ability and experience & 15.62 & 10 \\
\hline Improve the quality of provided construction documentation & 15.39 & 11 \\
\hline Reduce total costs & 14.94 & 12 \\
\hline Facilitate communications and interactions among stakeholders & 14.58 & 13 \\
\hline Increase the speed of updating changes in all dependent models & 14.2 & 14 \\
\hline Avoid same mistakes in different projects & 14.11 & 15 \\
\hline Help group decision-making & 14.08 & 16 \\
\hline $\begin{array}{l}\text { Decrease the time of decision-making process by using interactive } \\
\text { behaviors }\end{array}$ & 13.92 & 17 \\
\hline Develop constructability and implementation strategies & 13.88 & 18 \\
\hline $\begin{array}{l}\text { Improve understanding of design models by stakeholders during } \\
\text { evolution of models }\end{array}$ & 13.86 & 19 \\
\hline Improve the quality of design and construction & 13 & 20 \\
\hline Ensure effective information and knowledge management & 12.89 & 21 \\
\hline Improve cost estimation and estimation accuracy & 10.47 & 22 \\
\hline Decrease the time of request for information (RFI) and receiving them & 9.92 & 23 \\
\hline $\begin{array}{l}\text { Facilitate scenario simulation and prediction of project activities by } \\
\text { project team }\end{array}$ & 7.84 & 24 \\
\hline Reduce complicated bureaucracies and solve problems more easily & 7.52 & 25 \\
\hline Increase flexibility & 7.5 & 26 \\
\hline Facilitate resource management & 6.62 & 27 \\
\hline
\end{tabular}

Table 7 indicates that the significance level is zero and it is less than the level of alpha error 0.05, so the null hypothesis of "having equal importance among the benefits of applying VIM in successful completion of the project" is rejected and the alternative hypothesis of "differing importance of the benefits of applying VIM in successful completion of the project" is confirmed. Table 8 indicates that 
the average rating and the priority of 27 benefits in applying VIM influence the successful completion of projects. The most important benefits of applying VIM are "Achieve integrity and interactivity in business structures" with average rank of 19.58, "Optimize efficiency during all phases of the project" with average rank of 18.78 and "Achieve short timetables and improve effect on project time" with average rank of 18.55. The least important benefits are "Reduce complicated bureaucracies and solve problems more easily" with rank of 7.52, "Increase flexibility" with rank of 7.50 and "Facilitate resource management" with rank of 6.62 .

\subsection{One-Sample T Test for Analysis of the Challenges of VIM Application}

The results of statistical analysis for each challenge of VIM application are presented in Table 9 according to the areas of project management knowledge.

Table 9. One-Sample T Test Results for Evaluation of Challenges of VIM Application.

\begin{tabular}{|c|c|c|c|c|c|c|c|}
\hline \multirow{3}{*}{ Variables } & \multicolumn{6}{|c|}{ Test Amount $=3$} & \multirow{3}{*}{ Result } \\
\hline & \multirow[t]{2}{*}{$T$} & \multirow[t]{2}{*}{ df } & \multirow[t]{2}{*}{ Mean } & \multirow[t]{2}{*}{$\begin{array}{l}\text { Sig. } \\
\text { (2-Tailed) }\end{array}$} & \multicolumn{2}{|c|}{$\begin{array}{l}95 \% \text { Confidence } \\
\text { Interval of the } \\
\text { Difference }\end{array}$} & \\
\hline & & & & & Lower & Upper & \\
\hline $\begin{array}{l}\text { Need for multi-party } \\
\text { collaboration contracts }\end{array}$ & 2.273 & 31 & 3.5 & 0.03 & 0.0514 & 0.9486 & confirmed \\
\hline $\begin{array}{l}\text { Need to change processes of } \\
\text { project organization }\end{array}$ & 3.973 & 31 & 3.9688 & 0 & 0.4715 & 1.466 & confirmed \\
\hline $\begin{array}{l}\text { Lack of software } \\
\text { compatibility from one } \\
\text { project to another }\end{array}$ & 3.498 & 31 & 3.7812 & 0.001 & 0.3258 & 1.2367 & confirmed \\
\hline Integration & 3.821 & 31 & 3.75 & 0.001 & 0.3497 & 1.1503 & confirmed \\
\hline $\begin{array}{l}\text { Creating all models at the } \\
\text { optimum level of detail and } \\
\text { accuracy and reducing } \\
\text { design speed }\end{array}$ & 6.984 & 31 & 3.937 & 0 & 0.6637 & 1.2113 & confirmed \\
\hline Time & 6.984 & 31 & 3.937 & 0 & 0.6637 & 1.2113 & confirmed \\
\hline $\begin{array}{l}\text { Excessive cost of software } \\
\text { and hardware tools }\end{array}$ & -4.104 & 31 & 2.1875 & 0 & -1.2162 & -0.4088 & rejected \\
\hline $\begin{array}{l}\text { Creating training and } \\
\text { learning costs }\end{array}$ & -4.176 & 31 & 2.0938 & 0 & -1.3489 & -0.4636 & rejected \\
\hline $\begin{array}{l}\text { Controversy over who } \\
\text { should pay for VIM }\end{array}$ & 4.984 & 31 & 3.537 & 0 & 0.5227 & 1.1024 & confirmed \\
\hline Cost & -2.748 & 31 & 2.6051 & 0 & -0.6586 & -0.2813 & rejected \\
\hline $\begin{array}{l}\text { The need for all stakeholders } \\
\text { to agree on standards for } \\
\text { exchange between different } \\
\text { models }\end{array}$ & 1.561 & 31 & 3.218 & 0.129 & -0.067 & 0.5045 & rejected \\
\hline Stakeholder & 1.561 & 31 & 3.218 & 0.129 & -0.067 & 0.5045 & rejected \\
\hline $\begin{array}{l}\text { Need for a high level of } \\
\text { expertise }\end{array}$ & 9 & 31 & 4.125 & 0 & 0.0187 & 1.3799 & confirmed \\
\hline Human resource & 9 & 31 & 4.125 & 0 & 0.0187 & 1.3799 & confirmed \\
\hline $\begin{array}{l}\text { The existence of innovative } \\
\text { processes and the risk of } \\
\text { change }\end{array}$ & 3.215 & 31 & 3.5 & 0.003 & 0.1828 & 0.8172 & confirmed \\
\hline Risk & 3.215 & 31 & 3.5 & 0.003 & 0.1828 & 0.8172 & confirmed \\
\hline
\end{tabular}

\subsection{Friedman Test for Prioritizing the Challenges of VIM Application}

The Friedman Test was used to prioritize the challenges of applying VIM which were confirmed in the One-Sample $T$ Test. The results are shown in Tables 10 and 11. 
Table 10. Test statistics of Friedman test for prioritization of challenges of VIM application.

\begin{tabular}{cc}
\hline $\mathbf{N}$ & $\mathbf{3 2}$ \\
\hline Chi-Square & 48.008 \\
$\mathrm{df}$ & 6 \\
Asymp. Sig. & 0.000 \\
\hline
\end{tabular}

Table 11. Average rating of challenges of VIM application among confirmed challenges.

\begin{tabular}{lcc}
\hline \multicolumn{1}{c}{ Challenge } & Average Rating & Challenge Priority \\
\hline Need to change processes of project organization & 4.81 & 1 \\
\hline Need for a high level of expertise & 4.77 & 2 \\
\hline $\begin{array}{l}\text { Creating all models at the optimum level of detail } \\
\text { and accuracy and reducing design speed }\end{array}$ & 4.52 & 4 \\
\hline $\begin{array}{l}\text { Lack of software compatibility from one project to } \\
\text { another }\end{array}$ & 4.42 & 5 \\
\hline $\begin{array}{l}\text { Need for multi-party collaboration contracts } \\
\text { The existence of innovative processes and the risk of } \\
\text { change }\end{array}$ & 3.86 & 6 \\
\hline Controversy over who should pay for VIM & 3.66 & 7 \\
\hline
\end{tabular}

Table 10 indicates that the significance level is zero and it is less than the level of alpha error 0.05 , so the null hypothesis is rejected and the alternative hypothesis of "differing importance of the challenges of applying VIM in successful completion of the project" is confirmed.

Table 11 shows the priority of seven challenges in applying VIM which affect successful completion of a project. The three greatest challenges are "Need to change processes of project organization" with average rate of 4.81, "Need for a high level of expertise" with average rate of 4.77 and "Creating all models at the optimum level of detail and accuracy and reducing design speed" with average rate of 4.52. The least important challenge is "Controversy over who should pay for VIM" with average rank of 1.97 .

\section{Discussions}

The objective of the research was to investigate the benefits and challenges of applying virtual design and construction in projects and prioritize them based on project management knowledge areas. Through a literature review, the benefits and challenges were identified and a survey of 32 construction industry employees in Iran was used to confirm these benefits and challenges through statistical analysis. The 27 confirmed benefits of using VIM are presented in Table 12, by area of relevant project management knowledge and their priority. 
Table 12. Ranks of benefits of VIM application.

\begin{tabular}{|c|c|c|}
\hline Priority & $\begin{array}{l}\text { Project Management Knowledge } \\
\text { Area }\end{array}$ & Benefit \\
\hline 1 & Integration & $\begin{array}{l}\text { Achieve integrity and interactivity in business } \\
\text { structures }\end{array}$ \\
\hline 2 & Integration & Optimize efficiency during all phases of the project \\
\hline 3 & Time & $\begin{array}{l}\text { Achieve short timetables and improve effect on } \\
\text { project time }\end{array}$ \\
\hline 4 & Integration & $\begin{array}{l}\text { Provide useful and useable information during the } \\
\text { whole project life cycle }\end{array}$ \\
\hline 5 & Integration & $\begin{array}{l}\text { Ensure conjunction among fragmented construction } \\
\text { processes }\end{array}$ \\
\hline 6 & Cost & Consider the value of project as a whole \\
\hline 7 & Integration & Improve productivity \\
\hline 8 & Integration & $\begin{array}{l}\text { Increase integrity among product, working process } \\
\text { and organization in design-construction-operation } \\
\text { team }\end{array}$ \\
\hline 9 & Time & Decrease reworks \\
\hline 10 & Stakeholder & $\begin{array}{l}\text { Use for a wide range of companies and levels of } \\
\text { ability and experience }\end{array}$ \\
\hline 11 & Quality & $\begin{array}{l}\text { Improve the quality of provided construction } \\
\text { documentation }\end{array}$ \\
\hline 12 & Cost & Reduce total costs \\
\hline 13 & Communications & $\begin{array}{l}\text { Facilitate communications and interactions among } \\
\text { stakeholders }\end{array}$ \\
\hline 14 & Time & $\begin{array}{l}\text { Increase the speed of updating changes in all } \\
\text { dependent models }\end{array}$ \\
\hline 15 & Integration & Avoid same mistakes in different projects \\
\hline 16 & Stakeholder & Help group decision-making \\
\hline 17 & Time & $\begin{array}{l}\text { Decrease the time of decision-making process by } \\
\text { using interactive behaviors }\end{array}$ \\
\hline 18 & Scope & $\begin{array}{l}\text { Develop constructability and implementation } \\
\text { strategies }\end{array}$ \\
\hline 19 & Stakeholder & $\begin{array}{l}\text { Improve understanding of design models by } \\
\text { stakeholders during evolution of models }\end{array}$ \\
\hline 20 & Quality & Improve the quality of design and construction \\
\hline 21 & Integration & $\begin{array}{l}\text { Provide effective information and knowledge } \\
\text { management }\end{array}$ \\
\hline 22 & Cost & Improve cost estimation and estimation accuracy \\
\hline 23 & Time & $\begin{array}{l}\text { Decrease the time of request for information (RFI) } \\
\text { and receiving them }\end{array}$ \\
\hline 24 & Risk & $\begin{array}{l}\text { Facilitate scenario simulation and prediction of } \\
\text { project activities by project team }\end{array}$ \\
\hline 25 & Communications & $\begin{array}{l}\text { Reduce complicated bureaucracies and solve } \\
\text { problems more easily }\end{array}$ \\
\hline 26 & Scope & Increase flexibility \\
\hline 27 & Procurement & Facilitate resource management \\
\hline
\end{tabular}


Table 12 shows the benefits associated with the area of project integration management have higher priorities than other areas. The three main benefits of VIM are:

- Achieve integrity and interactivity in business structures;

- Optimize efficiency during all phases of the project;

- Achieve fast tacking approach and improve project schedule management plan.

Table 13 shows the seven challenges of adopting the virtual design and construction method by the area of project management knowledge and their priorities.

Table 13. Ranks of challenges of VIM application.

\begin{tabular}{ccl}
\hline Priority & $\begin{array}{c}\text { Project Management Knowledge } \\
\text { Area }\end{array}$ & \multicolumn{1}{c}{ Challenge } \\
\hline 1 & Integration & Need to change processes of project organization \\
\hline 2 & Human Resource & Need for a high level of expertise \\
\hline 3 & Time & $\begin{array}{l}\text { Creating all models at the optimum level of detail } \\
\text { and accuracy and reducing design speed }\end{array}$ \\
\hline 4 & Integration & $\begin{array}{l}\text { Lack of software compatibility from one project to } \\
\text { another }\end{array}$ \\
\hline 5 & Integration & $\begin{array}{l}\text { Need for multi-party collaboration contracts } \\
\text { Risk }\end{array}$ \\
\hline 7 & Cost & $\begin{array}{l}\text { The existence of innovative processes and the risk of } \\
\text { change }\end{array}$ \\
\hline
\end{tabular}

Just as the most important benefits of VIM are associated with the area of integration management, the greatest challenges posed by VIM are also related to this area. This indicates the importance of VIM in creating greater integration and also creating challenges, which highlights the need for efficient management in this area. The three main challenges of VIM are:

- Need to change processes of project organization as the project team will not be ready for changes.

- Need for a high level of expertise in VIM; this is not a new finding. All other papers about BIM saying the same thing.

- Detailed design must be accurate and optimal, and it needs to be complete in a shorter time.

Prioritization of project management knowledge areas regarding VIM benefits and challenges in AEC industry is one of the novelties of this research that can further contribute to the implementation of VIM in project management knowledge areas. This study found that integrating scope, time and cost are the most challenging section of VIM implementation for project managers in AEC industry. Although this study was conducted in Iran, it is generalizable to other regions and countries as well.

\section{Conclusions and Recommendations}

The results show that while VIM creates the greatest benefit in the area of project integration management, the greatest challenges are also in this area. VIM can support in a collection of processes required to ensure that the various elements of the projects are properly coordinated. VIM involves making trade-offs among competing objectives and alternatives to meet or exceed stakeholder needs and expectations. This highlights the importance of attention to all aspects of the use of VIM, specifically integration, and shows that even after the implementation of VIM the result is not always positive. The restrictions on data collection were imposed not only to maintain their privacy and sensitivity, but also because not enough project managers had implemented VIM in construction industry. Nevertheless, 32 usable survey responses, representing a $64 \%$ response rate, were collected, which was very rewarding considering the lack of such data in VIM and project management. 
In this research, the benefits and challenges of using virtual information modeling in construction projects were identified, based on the area of project management knowledge areas were categorized and then prioritized according to a survey among the people working in construction industry of Iran and being familiar with the concept of VIM. Although the respondents' understanding of the VIM concept were high, the benefits and challenges of implementing VIM was not clear enough. Based on our findings, we realized that they have not understood the integration of the project management knowledge areas and project managers in AEC industry need to be trained for the project management integration knowledge areas in using VIM.

While the benefits and challenges of using VIM for all areas of project management knowledge areas were considered simultaneously in the research, future research could investigate the benefits and challenges using a larger sample and from other countries and separately for each of the ten areas of project management knowledge. Additionally, as the society of people using basic functions of VIM in their projects is gradually expanding, this survey can be conducted in a larger society.

Author Contributions: N.D. conceived, designed and performed the experiments; M.T. contributed materials and analysis tools; M.M. and S.S. analyzed the data and wrote the paper.

Funding: This research received no external funding.

Conflicts of Interest: The authors declare no conflict of interest.

\section{References}

1. Stewart, R.A. IT enhanced project information management in construction: Pathways to improved performance and strategic competitiveness. Autom. Constr. 2007, 16, 511-517. [CrossRef]

2. Bowden, S.; Dorr, A.; Thorpe, T.; Anumba, C. Mobile ICT support for construction process improvement. Autom. Constr. 2006, 15, 664-676. [CrossRef]

3. Li, H.; Lu, W.; Huang, T. Rethinking project management and exploring virtual design and construction as a potential solution. Constr. Manag. Econ. 2009, 27, 363-371. [CrossRef]

4. Froese, T.M. The impact of emerging information technology on project management for construction. Autom. Constr. 2010, 19, 531-538. [CrossRef]

5. Froese, T. Emerging information and communication technologies and the discipline of project information management. In Intelligent Computing in Engineering and Architecture; Springer: Berlin, Germany, 2006; pp. 230-240.

6. Kunz, J.; Fischer, M. Virtual Design and Construction: Themes, Case Studies and Implementation Suggestions; Center for Integrated Facility Engineering (CIFE), Stanford University: Stanford, CA, USA, 2009.

7. Khanzode, A.; Fischer, M.; Reed, D.; Ballard, G. A Guide to Applying the Principles of Virtual Design $\mathcal{E}$ Construction (VDC) to the Lean Project Delivery Process; CIFE, Stanford University: Palo Alto, CA, USA, 2006.

8. Skibniewski, M.A.J.; Zavadskas, E.K. Technology development in construction: A continuum from distant past into the future. J. Civ. Eng. Manag. 2012, 19, 136-147. [CrossRef]

9. Arditi, D.; Kale, S.; Tangkar, M. Innovation in Construction Equipment and Its Flow into the Construction Industry. J. Constr. Eng. Manag. 1997, 123, 371-378. [CrossRef]

10. Ofori, G. Construction Industry Development: Role of Technology Transfer. Constr. Manag. Econ. 1994, 12, 379-392. [CrossRef]

11. Tatum, C. Classification System for Construction Technology. J. Constr. Eng. Manag. 1988, 114, $344-363$. [CrossRef]

12. Sepasgozar, S.M.E.; Leonhard, E.B. A technology pre-adoption model for construction. In Proceedings of the 37th AUBEA International Conference, UNSW, Sydney, Australia, 4-6 July 2012.

13. BuildingSmart, International Home of OpenBIM. Available online: https://www.buildingsmart.org/ (accessed on 21 May 2018).

14. Dainty, A.; Leiringer, R.; Fernie, S.; Harty, C. BIM and the small construction firm: A critical perspective. Build. Res. Inf. 2017, 45, 696-709. [CrossRef]

15. Kassem, M.; Succar, B. Macro BIM adoption: Comparative market analysis. Autom. Constr. 2017, 81, $286-299$. [CrossRef] 
16. Lu, Y.; Wu, Z.; Chang, R.; Li, Y. Building Information Modeling (BIM) for green buildings: A critical review and future directions. Autom. Constr. 2017, 83, 134-148. [CrossRef]

17. Kam, C.; Senaratna, D.; Xiao, Y.; McKinney, B. The VDC Scorecard: Evaluation of AEC Projects and Industry Trends; CIFE: Maharashtra, India, 2013.

18. Rogers, E.M. Diffusion of Innovations, 4th ed.; Free Press: New York, NY, USA, 2010.

19. Sepasgozar, S.M.E.; Loosemore, M.; Davis, S.R. Conceptualising information and equipment technology adoption in construction: A critical review of existing research. Eng. Constr. Architect. Manag. 2016, 23, 158-176. [CrossRef]

20. Rogers, E.M. Diffusion of Innovations, 4th ed.; Free Press: New York, NY, USA, 1995.

21. Davis, F.D.; Bagozzi, R.P.; Warshaw, P.R. User Acceptance of Computer Technology: A Comparison of Two Theoretical Models. Manag. Sci. 1989, 35, 982-1003. [CrossRef]

22. Venkatesh, V.; Bala, H. Technology Acceptance Model 3 and a Research Agenda on Interventions. Decis. Sci. 2008, 39, 273-315. [CrossRef]

23. Nicolini, D.; Holti, R.; Smalley, M. Integrating project activities: The theory and practice of managing the supply chain through clusters. Constr. Manag. Econ. 2001, 19, 37-47. [CrossRef]

24. Nikas, A.; Poulymenakou, A.; Kriaris, P. Investigating Antecedents and Drivers Affecting the Adoption of Collaboration Technologies in the Construction Industry. Autom. Constr. 2007, 16, 632-641. [CrossRef]

25. Harty, C. Implementing Innovation in Construction: Contexts, Relative Boundedness and Actor-Network Theory. Constr. Manag. Econ. 2008, 26, 1029-1041. [CrossRef]

26. Sepasgozar, S.M.; Costin, A.; Wang, C. Challenges of Migrating from Desktop-based BIM in Construction. In Proceedings of the 33rd International Symposium on Automation and Robotics in Construction (ISARC 2016), Auburn, AL, USA, 18-21 July 2016; pp. 934-942.

27. Milliou, C.; Petrakis, E. Timing of technology adoption and product market competition. Int. J. Ind. Organ. 2011, 29, 513-523. [CrossRef]

28. IBM. Innovation Index of Australian Industry; Melbourn Institute of Appliad Economic and Social Research: Melbourn, UK, 2010; pp. 1-24.

29. Hinsch, A.; Behrens, S.; Berginc, M.; Bönnemann, H.; Brandt, H.; Drewitz, A.; Einsele, F.; Faßler, D.; Gerhard, D.; Gores, H.; et al. Material development for dye solar modules: Results from an integrated approach. Prog. Photovolt. Res. Appl. 2008, 16, 489-501. [CrossRef]

30. Hinsch, A. Technology Trends—Dye Solar Cells, 30 June 2011 ed.; INFOTHE Co., Ltd.: Goyang-si, Korea, 2011.

31. Cleveland, A. Emerging Tools to Enable Construction Engineering. J. Constr. Eng. Manag. 2011, 137, 836-842. [CrossRef]

32. Munkvold, B.E. Challenges of IT implementation for supporting collaboration in distributed organizations. Eur. J. Inf. Syst. 1999, 8, 260-272. [CrossRef]

33. Australian Bureau of Statistics (ABS). Innovation in Australian Business; Australian Bureau of Statistics: Canberra, Australia, 2009.

34. Vessey, I.; Ramesh, V.; Glass, R.L. Research in Information Systems: An Empirical Study of Diversity in the Discipline and Its Journals; M.E. Sharpe, Inc.: Armonk, NY, USA, 2002; Volume 19, pp. 129-174.

35. Venkatesh, V.; Morris, M.G.; Davis, G.B.; Davis, F.D. User acceptance of information technology: Toward a unified view. MIS Q. Manag. Inf. Syst. 2003, 27, 425-478. [CrossRef]

36. Howard, J.A.; Moore, W.L. Changes in Consumer Behavior over the Product Life Cycle. In Readings in the Management of Innovation; Pitman: Marshfield, MA, USA, 1988; p. 2.

37. Damanpour, F.; Schneider, M. Phases of the Adoption of Innovation in Organizations: Effects of Environment, Organization and Top Managers. Br. J. Manag. 2006, 17, 215-236. [CrossRef]

38. Ajzen, I.; Fishbein, M. Attitude-behavior Relations: A Theoretical Analysis and Review of Empirical Research. Psychol. Bull. 1977, 84, 888. [CrossRef]

39. Rahman, M. Barriers of Implementing Modern Methods of Construction. J. Manag. Eng. 2014, 30, 69-77. [CrossRef]

40. Organisation for Economic Co-operation and Development. Sickness, Disability and Work: Breaking the Barriers: A Synthesis of Findings across OECD Countries; OECD Publishing: Paris, France, 2010.

41. Sepasgozar, S.M.E.; Bliemel, M.J.; Bemaian, M. Discussion of "Barriers of Implementing Modern Methods of Construction" by M. Motiar Rahman. J. Manag. Eng. 2015, 32, 07015001. [CrossRef] 
42. Miller, A.; Radcliffe, D.; Isokangas, E. A perception-influence model for the management of technology implementation in construction. Constr. Innov. Inf. Process Manag. 2009, 9, 168-183. [CrossRef]

43. Love, P.; Irani, Z. An Exploratory Study of Information Technology Evaluation and Benefits Management Practices of SMEs in the Construction Industry. Inf. Manag. 2004, 42, 227-242. [CrossRef]

44. Slaughter, E.S. Implementation of construction innovations. Build. Res. Inf. 2000, 28, 2-17. [CrossRef]

45. Stewart, W.; Tatum, C. Segmental Placement of Renton Outfall: Construction Innovation. J. Constr. Eng. Manag. 1988, 114, 390-407. [CrossRef]

46. Snyder, C.S. A Guide to the Project Management Body of Knowledge: PMBOK ${ }^{\circledR}$ Guide; Project Management Institute: Newtown Square, PA, USA, 2014.

47. Azhar, S. Building information modeling (BIM): Trends, benefits, risks, and challenges for the AEC industry. Leadersh. Manag. Eng. 2011, 11, 241-252. [CrossRef]

48. Eastman, C.M.; Eastman, C.; Teicholz, P.; Sacks, R. BIM Handbook: A Guide to Building Information Modeling for Owners, Managers, Designers, Engineers and Contractors; John Wiley \& Sons: Hoboken, NJ, USA, 2011.

49. Teixeira, H. VDC Implementation in Transport Infrastructure Projects. Master's Thesis, Institutt for Bygg, Anlegg og Transport, Trondheim, Norway 2014.

50. Chachere, J.; Kunz, J.; Levitt, R. Observation, Theory, and Simulation of Integrated Concurrent Engineering: Grounded Theoretical Factors that Enable Radical Project Acceleration; CIFE WP: San Francisco, CA, USA, 2004; p. 87.

51. Lahdou, R.; Zetterman, D. BIM for Project Managers How Project Managers Can Utilize BIM in Construction Projects; Chalmers University of Technology: Göteborg, Sweden, 2011.

52. Fischer, M.; Kunz, J. The scope and role of information technology in construction. In Proceedings of the Japan Society of Civil Engineers; Japan Society of Civil Engineers: Tokyo, Japan, 2004; pp. 1-32.

53. Mahalingam, A.; Kashyap, R.; Mahajan, C. An evaluation of the applicability of 4D CAD on construction projects. Autom. Constr. 2010, 19, 148-159. [CrossRef]

54. Alborzi, S.; Aminian, A.; Mojtahedi, S.M.H.; Mousavi, S.M. An analysis of project risks using the non-parametric Bootstrap technique. In Proceedings of the IEEM: 2008 International Conference on Industrial Engineering and Engineering Management, Singapore, 8-11 December 2008; pp. 1295-1299.

55. Ebrahimnejad, S.; Mousavi, S.M.; Mojtahedi, S.M.H. A Fuzzy BOT Project Risk Evaluation Model in Iranian Power Plant Industry. In Proceedings of the 2008 IEEE International Conference on Industrial Engineering and Engineering Management, Singapore, 8-11 December 2008; pp. 1038-1042.

56. Ebrahimnejad, S.; Mousavi, S.M.; Mojtahedi, S.M.H. A Model for Risk Evaluation in Construction Projects Based on Fuzzy MADM. In Proceedings of the 2008 IEEE International Conference on Management of Innovation and Technology, Bangkok, Thailand, 21-24 September 2008; Volumes 1-3, pp. 305-310. [CrossRef]

57. Bland, J.M.; Altman, D.G. Statistics notes: Cronbach's alpha. BMJ 1997, 314, 572. [CrossRef] [PubMed] 